\title{
THEORETICAL AND APPLIED ASPECTS OF BASIC R\&D DURING THE PERIOD OF TRANSITION TO POST-INDUSTRIAL KNOWLEDGE ECONOMY
}

\author{
Ameen Saif Ali Al-Ghazali \\ Central Ukrainian National Technical University, Kropyvnytskyi, Ukraine \\ Ministry of Defense, Diplomatic corps, Sanaa, Yemen \\ abosultan711@hotmail.com
}

Received: 21 September 2020; Accepted: 08 December 2020; Published: 27 January 2021

\begin{abstract}
The subject of the study are theoretical and applied aspects of the implementation of fundamental $R \& D(F R \& D)$, the essence of which is the constant expansion of resources of social consumption and the formation of high-risk sources of increasing the level of collective well-being; promoting consolidated and sustainable development; management of the design and structure of a complex of unprocessed assets of national wealth, produced by real sector of national economy goods / services provided by social sector of national economy, material and intangible values with a high potential of value added production; formation of high-tech services based on the use of basic concepts and satisfaction of consumer expectations in them; development of logically justified formatin of fundamental science theoryn, renewal and use of fundamental science knowledge, concepts and sensual-figurative models of the world' science picture with opportunities for further use in public practice; increasing the level of trust and reciprocity, improving the physical and psychological well-being of members of network communities by setting up relations of understanding and mutual support of carriers of values of social and scientific capital - participants in the processes of forming the intellectual potential of local social networks of institutional agents of the post-industrial knowledge economy.

The research method is to summarize the theoretical and applied aspects of the modern stage of FR\&D' implementation in cognitive society, which is associated with a critical analysis of the results of theoretical research in the field of gnoseology, as well as the study of features of the implementation of applied theories of changing the scientific paradigms of leading scientists of our time.

The result of the study is the formation of an integrated approach to the implementation FR\&D in the context of a direct transition to the post-industrial knowledge economy.

The definition of the need for the implementation of $F R \& D$ as an emotional state capable of creative social group of research scientists and society as a whole is formulated, which expresses dependence on the objective content of conditions of existence and development and acts as a source of various forms of activity in the public interest. The potential of FR\&' implementation is defined as the ability to intensify the processes of purposeful, costly, long-term nonlinear, multi-stage and cumulative learning, which leads to interactive, technologically specialized and culturally determined constant innovation activities of research universities with the subsequent receipt of market advantages.
\end{abstract}

Key words: fundamental $R \& D$, cognitive society, need for the implementation of FR\&D, potential of FR\&' implementation

JEL classification: A11; I20; I23

\section{Citation:}

Al-Ghazali A.Saif Ali. 2021. Theoretical and applied aspects of basic R\&D during the period of transition to postindustrial knowledge economy. Access to science, business, innovation in digital economy, ACCESS Press, 2(1): 103115. https://doi.org/10.46656/access.2021.2.1(8)

\section{INTRODUCTION.}

Fundamental scientific research (FR\&D) - primary surveys, experimental or theoretical works carried out by curiosity driven research in order to obtain new knowledge about the fundamental properties of phenomena 
and observed facts without any specific purpose of application, which are regarded as pure public good (Oslo manual, 2005).

Rapid and irreversible transformation of traditional industrial society into a globalized post-industrial, accelerated and emphasized saturation with high-tech elements of dominant technological processes, further improvement of the level and quality of collective and personal well-being of stakeholders clustered innovatively oriented ecosystems objectively associated with the transformation FR\&D from a kind of peripheral elitist activity to the main focus of the development of postmodern cognitive society.

The ancient period of FR\&D instinct is associated with the introduction of the practice of critical discussion of conditions for obtaining true knowledge with the central problem of passive relation between compulsory, stable, objective knowledge (in compulsory unity with its subject) and problematic knowledge, including correct, as well as illusory, false, unreliable, truth and delusion. The absence of a fundamental logical contrast between the subject and the object of cognitive activity is associated with the fact that the theory of cognition (ToC) exists for ancient thinkers only in connection with the task of constructing a picture of space. Development of the theory of cognition in the New Time, which was associated with the search for absolutely reliable knowledge, updating the paradigm of the FR\&D during the XVII-XVIII centuries. explained by the fact that at this time the first roles are the need to limit the substantiation of the entire set of accumulated knowledge, their assessment according to the degree of truth. Analysis of problems of cognition theory in the philosophy of the twentieth century is characterized by a number of features. Marxist-Leninist current of philosophy one of its sources declared classical German. The fundamental difference between dialectical materialism (Marx-Engels line) and gnoseological idealism (Kant-Hegel line) in matters of development of the theory of cognition, which is directly related to the organization of the FR\&D, is observed in the following elements:

- the material world is recognizable, the objective reality exists outside and regardless of consciousness, in general the world is gnostic;

- dialectic materialism considers ontological and gnoseological aspects of philosophical problems in their unity - dialectics, logic and theory of cognition are the only ones;

- the essence and nature of cognition are social in nature and cannot be understood in isolation from subjectpractical activities;

- the confrontation to idealistic and metaphysically interpreted sensationalism is declared, the irredience of real cognition to simple summation or mechanistic transformation of sensational data is emphasized;

- empirical data operated by science are formed in the process of using theoretical provisions to describe the content of sensory experience and involves a number of theoretical idealizations that should simultaneously be understood as a moment of active practical sensual and subjective activity;

- theoretical thinking is guided by the reproduction of the object of cognition by ascent techniques from abstract to specific, inextricably linked with the principles of unity of logical and historical, analysis and synthesis; 
- categories and laws of materialistic dialectics are not only forming of reflection of objective reality, but also methodological principles of scientific and theoretical activity;

- cognitive process is considered not so much in the form in which the individual is carried out in the head, so much in the form of a socio-historical process of knowledge development;

- the use of the dialectical-materialistic principle of Historicism is combined with the recognition of the specific historical nature of the basics of knowledge, is a means of overcoming Gnoséological relativism, the development of the doctrine of the dialectic of absolute and relative truth;

- social practice acts as the basis, the purpose of knowledge, the criterion of truth;

- theory of cognition $\neq$ the theory of reflection, the process of cognition proceeds not in the form of passive monitoring from the outside of these objects, but in the form of a number of ideal actions organized into the system, operations that form some ideal objects that serve as a means for cognitive assimilation, reflection of the objective world;

- the process of human reflection is inextricably linked with the processes of material and ideal creativity;

- theory of cognition is not methane science, theoretical and cognitive interpreting of science begins where theoretical structures are interpreted in terms of correspondence of reality, truth, ability to grant the status of existence to used abstract objects, to evaluate as analytical or synthetic statements of this scientific sphere;

- gnoseological interpreting of specific scientific theories acts, on the one hand, as the application of general principles of cognition theory to the analysis of specific cases, on the other - as a kind of assimilation of new scientific results for clarification, sometimes viewing some common gnoseological postulates. Development may require a new gnoseological interpretation of scientific theories (Marx \& Engels, 1969; Engels, 1985; Engels, 2013).

\section{METHODOLOGY.}

The research methodology focuses on the generalization of theoretical and applied aspects of the modern stage of formation of the basics of FR\&D implementation and is associated with a critical analysis of the results of theoretical research in the field of Neocantian "pure gnoseology" identifying philosophy with the theory of cognition (Bogomolov, 1969); their critics from the camp of transcendental ontologists (Husserl, 1994), empiric psychologists (Frank, 2007); representatives of the conglomerate of idealistic empiricalism and ontology - empirical critics, English neo-realists, "sensibulists", American neo-realists (James \& Russel, 2000; Bogomolov, 1962); linguistic analysts (Gryaznova, 1993); followers of the line: positivism (Narsky, 1961) neopositivism of scientical logical positivism (Ayer, 1959; Achinstein \& Barker, 1969) - linguistic philosophy (Charlesworth, 1959) - the logical pragmatism of the change of truth (instrumentalism, fallibism, anti-realism, radical empirism, verifiationism) (James \& Russel, 2000; Dewey, 2001) - post-positivism (Panin, 1981; Carnap,1971), as well as the implementation of applied theories of changing scientific paradigms and prolifers Karl Raimund Popper, Imre Lakatos, Thomas Samuel Kuhn, Paul Karl Feyerabend. 


\section{RESULTS AND DISCUSSION.}

Logical positivist, verifier, developer of the theory of probabilistic logic Karl Raimund Popper, on the development of scientific views of which was significantly influenced by the development of Alfred Tarski methodology of deductive sciences (Tarsky, 1948), saw strategic prospects for the development of the field of production of the FR\&D (in terms of demarcation of scientific knowledge from unscientific, as well as induction - the advancing of inductive judgments from experience) in the direction and discourse of research of the peculiarities of the development of scientific knowledge (Popper, 2005) in universities as key specific forms of social organization of the process of production of knowledge resources of post-industrial society. According to the author's concept, according to which the existence of a special philosophical method of fundamental science theory (FST) analysis was denied, this recognized the method of any "critical rational discussion", which provided for a clear problem set and analysis of various proposed solutions.

Applying in practice the post-positivist principle of fallibilis (from lat. fallibilis - prone to mistakes, errors) Charles Sanders Peirce, arguing that truth is objective, and knowledge is the nature of assumptions, the scientist simultaneously and, to a certain extent, inconsistently, criticized the concepts that consider universal laws and theory as rules, erect instructions for the withdrawal of single expressions opposed the concepts by which science adequately describes the essence of things (Popper, 1983), while recognizing the ability to make real discoveries through science's research of objective (transsubbiatic) phenomena of reality (Popper, 1956).

An applied result of the practical application of the Popper concept in the field of FR\&D implementation can be considered probiliistic (from Lat. probabilis - probabilis) style of scientific cognition, the principle of verifying the intermediate interpretation of the truth, belonging of statements about it to empirical science and denial of the suitability of the application of the deterministic method of scientific thinking, the logic of Por Royal (Rene Descartes and Blaise Pascal), metaphysics, psychoanalysis and individual psychology Alfred Adler to substantiate the partial and acceptable value of scientific theories as points in the continuum of inaccuracy and uncertainty (line Hume/Berkeley vs. Bacon/Newton).

Overcoming uncertainty and inauthenticity is possible on the way to adhere to the four-step scientific method Popper, which is obliged to adhere to the developer of FST:

- stage of nomination of the theoretical hypothesis (by intuitive formulation or scientific rethinking of metaphysical idea), which is designed to contribute to solving the problematic situation; stage of preliminary assessment of the courage of the hypothesis, which the researcher drew attention to (has proved its mettle), for further work with it on the basis of falsification criteria, which is directly proportional to the degree of risk; derive from the theoretical hypothesis the consequences that can be checked empirically;

- election among the consequences of those that have a fundamentally new character; conducting experiments on their verification; making a decision on the results of the inspection; comparison of the test results with the consequences of the theory that are being tested; 
- deciding on the further use of the hypothesis, the possibility of assigning it the status of an "explanatory theory" on the basis of the principle of "modus tollens" - refusal to identify the context of checking the theory with the context of justification, adopting the theory not because it received a positive experience justification, but because it has not been refuted until now. That is, this theory has not yet been confirmed by the facts, but is temporarily supported (corroborated).

In general, Popper rejects the interpretation of the Francis Bacon method as a set of rules, techniques for obtaining true knowledge, justification of the reliability of the theory.

The method ceases to be a path to truth and is defined only as "our manner of dealing with scientific statements", the convention on scientific research, "the rules of the game in empirical science" (Popper, 2005). At the same time, the following restrictions are imposed on the path of adherence to the meta-corrected formulation of scientific theory as "rules of the highest type of warning against the inadmissibility of falsification", the following restrictions are imposed on "convention strategists":

firstly, the introduction of additional hypotheses is allowed only when they lead not to a reduction in the level of falsification / checking of the theoretical system, but to increase it;

secondly, changes in the definition of concepts are permissible in the case of their usefulness, but they should be considered as reformulation of the theory.

The specifics of the concept of objectivity, desubialization of scientific knowledge, its logical determinism, ability to intersubjective verification, independence from the knowing subject, popper is considered in relation to three pluralistic types of reality - the physical world (the world of physical states); world of states of consciousness (psychological world); world of fundamental science knowledge (FSK) ("world of objective states of thinking") as a set of theoretical systems, problems and problematic situations, critical arguments, the content of magazines, books and libraries.

The idea of his "Structure of Scientific Revolutions" Thomas Samuel Kuhn (2001) simultaneously directed against the theorical and philosophical position of antihistorism neo-oppositionists and falsification of critical rationalists (line Popper (2002) -Agassi (1968) - methodological postulate on "strong-willed basis" (Willenshintergrund) adoption of the original principles of science H. Albert (Albert, 1987) - pan (general) critical rationalism Bartley (1964) - Schpinner (1978).

The process of paradigm shift, as Kuhn describes, is the goal and content of the cyclical development of science, and the logical sequence of scientific revolutions involves the sequential passage of the stages of formation of the FR\&D.

Methodological and practical aspects of the theory of cyclical development of "normal science" T. Kuhn (Kuhn, 2001) have a significant impact on the formation of effective models of organizational and economic mechanism of FR\&D regulation, the content of which is envisaged for detailed consideration in the following sections of researches.

The concept of sophisticated falsificationism by critical conventionist Imre Lakatos (Lacatos, 2008), author of the concept of "mature" science as a "methodology of research programs" (MRP), was formed in the critical 
development of the post-positivism variant of K. Popper under the influence of another researcher of his creative achievement Agassi (1955).

Overcoming the problem of determining the "quasi-empirical basis" of assessing the capacity of methodological doctrines, I. Lakatos explores the phenomenon of striking stability of non-disparate scientific theories in the usual sense of the word, and the RP to empirical anomalies, proposes to comprehensively consider the facts of the history of science, which demonstrate the constant simultaneous presence of contradictory RP to explain the same set of phenomena. A competitive RP is a series of basic ideas and principles (consisting of four main elements) of theories that evolutionarily change each other.

The first and main element, the core of the program, evidence of the "maturity of science", the main unit of the FSK's translational development, are conventionally agreed and adapted by the professional community of specific scientific and ontological fundamental assumptions that are invariably preserved in the process of further development and implementation of the RP.

The safety belt (the second element) consists of a set of auxiliary hypotheses surrounding the nucleus and taking on the blows of attempts at experience refutations of the RP core. In the process of development of the SE, the protective belt may change, even completely, and the changes themselves are caused by the rules of heuristics of the program.

Negative heuristics (the third element) consists in the implementation of a methodological solution not to assume empirical refutation of the core of the program, the introduction of programs and rules that allow this solution to be implemented. In other words, negative heuristics are designed to reject empirical refutations that "run" on the basis of the "modus tollens" principle from the core of the program to the safety belt. To do this, hypotheses are created in order to explain anomalies, and "modus tollens" is directed at them.

Positive heuristics (the fourth element) consist of a set of rules contributing to the positive development of the RP, as well as "a partially developed set of proposals or hints that indicate how to change, develop debunked program options, modify, refine the debunked protective belt". An important function of positive heuristics is the ability to conduct "planned" studies, to predict possible empirical "anomalies" in advance, to develop refutation processing strategies, to develop/improve hypotheses. The real development of RP is due to the absorption of anomalies according to the rules of positive heuristics.

If conventionalism is assumed in the case of the adoption of the core of the program and both heuristics, then theories are directly conditioned by the nucleus and the rules of the positive. The involvement of these arguments explains the high anti-empirical stability of the theory - arbitrary counterproductive, at least for a certain time, is considered as an anomaly, a possible denial of the theory, and not its final refutation (Bantash, Koval, Bashynska, Kozlovtseva, 2020). That is, the MRP concept allows us to consider the amendments introduced to the theory in accordance with the canons of positive heuristics as its continuous development. A consistent series of theories - stages of development of the same RP.

The search for the criterion of success of the RP, its heuristic value makes it possible to distinguish two fundamentally possible stages of its development. Progressive, in which the main role is played by positive 
heuristics, is characterized by an increase in the empirical content of the protective field of auxiliary hypotheses, while theoretical growth, the ability to successfully predict new facts with obvious success, is ahead of the empirical. Regressive, characteristic of which is the focus of efforts not on the development of hypotheses, but on late protection against accidentally open / open with the use of competing RP counterexeds with the help of negative heuristics, has as a result of saturation of the protective belt hypotheses that are weakly related to the hard core. As a result, at the point of such "saturation" of the RP, the protective belt disintegrates, and an alternative one comes to replace it. Unfortunately, and this is recognized by the author himself, the item "saturation" of the RP can be determined only retrospectively. It is fundamentally important to have competing /competing RPs, because only under such conditions the experience begins to act as a decisive factor in their assessment.

The elegance of falsification of the old scientific theory with the advent of a new one is manifested if it meets the following requirements: first, the new one has additional empirical content, provides for new facts that are incredible from the point of view of the old one; secondly, the new theory simultaneously explains all the postulates of the previous one; thirdly, some of the additional content of the new theory is confirmed.

The epistemological approach to describing the structure of the FSK Paul Feyerabend (Feyerabend, 2020) was most fully manifested in the refusal to use his antithesis "empirical - theoretical". The essence of the approach is a creative combination of the provisions of critical rationalism, the scientific position of the late Ludwig Wittgenstein (Wittgenstein, 1969), "scientific materialism" and the ideology of counterculture. In contrast to the hypothetical-deductive model of science and gnoseological cumulativeism (the line of uncritical generalization of the practice of descriptive natural science and the ideal of deductive discretion, simple accumulation of knowledge, adding new to the existing, relatively uniform growth), in the discourse post of positivist criticism of nepopositivism, all knowledge, both domestic and scientific, is declared completely dependent on the assimilated philosophical-theoretical setup, moreover, on the worldview and psychological orientation of the subject of knowledge. For these reasons, the evaluation of theoretical knowledge, based solely on its experience verification, is declared unconvinced, and, from the point of view of consistently conducted principles of empirism itself. "Theoretical realism" blames the experience on excessive "theoretical overload", bias.

Versions of the growth of knowledge by increasing its empirical content (the theory of verification of the reliability of scientific theories based on the coincidence of inductive generalizations William Whewell - I. Lakatos and a rationalistic version of the NonKantians and neopositivist, which interprets the development of knowledge as such a sequence of abstract principles and theoretical explanations, each subsequent element of which includes the previous one, contrasts with the thesis of the inconsistency of Wittgenstein' theories, radical conventionism of Ajdukiewicz K., as well as the dialectical concept of knowledge development.

According to the principle of non-proportionality in the empirical sense (incommensurability of theories), the avtaric FST is not associated with logical relations, use different concepts, methods and means of vision of the world, are not logically comparable, and the choice between them is carried out only on the basis of 
worldview and socio-psychological preferences. The history of science is a discrete process that is devoid of continuity, and the scientific community is a disparate group of individuals, attracted to their own theory and not understanding opponents. As a result, logic cannot be the basis of scientific rationality, so it should necessarily include social and psychological dimensions. The methodology of science, which does not have clear criteria for the choice of theory, loses its normative character, is closed with sociology and the history of scientific knowledge.

"Anarchist theory of cognition" is opposed not only to the non-opposition philosophy of science, but also to the theory of K. Popper. As for refuting the latter's approach, since experience cannot testify to "for" or "against" the theory, the concepts of "anomaly" and "counter-contraindation" lose their meaning. According to the author of the concept of "anarchic theory" "... cognition is not a process that approaches some ideal. It is manifested in this case by an ocean of alternatives, the number of which is constantly increasing; each of which encourages others to clarify their points of view, and together they contribute - through the process of competition - to the development of the power of our thinking" (Feyerabend, 1969). Epistematic anarchism also differs from consonant ideas of skepticism and political anarchism.

If the credibility of the experience is redundant, and the procedures of empirical verification of theories are absolutely reliable, after the theory has been verified or fully confirmed, and the experience can no longer threaten it, it is prone to turning into metaphysical dogma. Theoretical and methodological pluralist Feyerabend declares: there are a large number of equal types of knowledge, this circumstance contributes to the growth of knowledge and personality development. The absence of a neutral observation language, in which experience is recorded, is manifested in its dogmatization, "theoretical overload", on the one hand, makes it impossible to form single "metastandards" that allow comparing the ideas about science themselves. Sociological interpretation of cognition, rejection of the concept of truth and objectivity of knowledge, relativity of the criteria of rationality in cognition and activity allows to formulate the basic principles of "anarchist epistemology", which is based on the denial of the universal method of cognition, its incompatibility with creative thinking (Petrova et al., 2020). A good empirist is willing to work with many alternative theories, not just one point of view and "experience" (Feyerabend, 1978).

The means of resisting the stagnation of paradigms, dogmatism (monism) on the way to the development of the FR\&D is the introduction of the principle of proliference. The implementation of the principle is seen in the recognition of the fact of spontaneous development of the process of cognition, chaotic intertletization of all forms of consciousness and activity. The only universal principle of cognition is "anything goes", the essence of which is as follows: (a) a scientist has the right to use any convenient methods and approaches in the process of inventing new theories and methods, since none of them is decisive and unmistakable (the principle of proliferation); (b) it is impossible to succeed unless paradigms are recognized from time to time, despite being incomplete (principle of perseverance).

Denying the traditional principles of verification and falsification, the author emphasizes the importance of psychological conviction, political interference in science as a means of ensuring the progress of knowledge. 
Each FST represents a closed world of a group of scientists, so its criticism and refutation are not enough exclusively scientific means. "Irrationality" causes the need to equalize science in rights with other types of human activity (myth-making, occupation of magic) and thereby put an obstacle to scientism ( non-critical confidence in the ability of science to solve all social problems, approach to it as a "pure", value-neutral "great science") - in the form of technocratic concepts of the "revolution of scientists" John Kenneth Galbraith (Galbraith, 1985), the concept of "deideologization" of industrial society Daniel Bell (Bell, 1973), neopositivism - as a separate ideology.

The unconditional achievements of Feyerabend's creative work are the idea of theoretical pluralism, "liberal pragmatism", the idea of empirical knowledge dependence on theoretical, the problem of historical conditionality of ideas about science. In relation to pluralism, two of its types differ - theoretical and methodological. If the first is to state the possibility of simultaneous existence of various theoretical systems, then methodological, which is formed on the basis of theoretical, requires the nomination of incomparable theoretical structures in order to develop scientific knowledge, which has characteristic features of the highest quality due to criticality, constant progress, as well as the implementation of normative methodological rules. The comparison is able to provide the choice of the best theory only if a "strict alternative" is formula, even if the sequence of knowledge development is disturbed. "Strict alternative" must meet the requirements: (1) proliferation, which is able to provide knowledge of another species, the creation of an incomparable theory, and not just a cumulative effect, obtaining more complete knowledge within the previous paradigm; (2) to implement the specific anti-instrumentalism of the FST (reality exists regardless of knowledge about it, knowledge is only an image of reality), the ability of the theory to act only as a means of prediction, which in no way reflects reality, while denying its dependence on empirical facts, because it is only a means of personality development, and not a reflection of reality; (3) not based on empirical reproductionism (not to reduce theoretical knowledge to empirical), but rather to reduce empirical knowledge to theory. Knowledge is best studied by analyzing scientific knowledge; since science is completely rational, it is possible a methodology that gives an adequate, independent of external factors, a description of the structure and development of knowledge; delusions in science and methodology should be overcome by special scientific and methodological means.

In general, the characteristic features of the methodological approach in question are: pluralism and cumulativeism in the understanding of knowledge development; realism in interpreting the attitude of knowledge to reality; anti-reductionism in assessing the mutual relationship of empirical and theoretical knowledge.

Although the late Feyerabend's antisceitism and episthemologic radicalism are not compatible with academic philosophy, his ideas are deeply rooted in the modern methodology of science (the absolute negativity of representatives of the Frankfurt School - Horkheimer M., Wiesengrund-Adorno T., Fromm E., Marcuse G., Habermas J, existential dialectics Husserl E., Heidegger M., Gadamer H.), sociology of scientific knowledge (replacing the sociological paradigm of Merton R. (Merton, 1973) "strong sociology paradigm of 
knowledge" Barnes B. (Barnes, 1974; Barnes \& Shapin, 1979); program "anthropology of knowledge" Yehuda Elkana (Elkana, 1981). Elkana' program "anthropology of knowledge", abandoning logic and methodological models, prefers cultural, hermetic and anthropological methods of knowledge analysis.

The latter proclaims science as a subsystem of culture and recognizes behind it the plurality of incarnations, which are determined by sociocultural and national contexts of origin and development. The author explains the pluralism of science by the influence of three factors: first, the connection of the process of cognition with different systems of scientific metaphysics; secondly, the coexistence of different "social images of science", caused by historical and intercultural differences; thirdly, the direct influence of socio-economic factors, which are different for different countries and epochs, on the nature of scientific institutions and the structure of the scientific community.

\section{CONCLUSION.}

FR\&D in the context of a direct transition to the post-industrial knowledge economy should be considered as pure social good, characterized by a number of features: (a) the benefit acts as a social, indivisible, total and non-exclusive, indiscriminate, indiscriminate in consumption, noncompetitive, localized to use by the elite scientific community; (b) the benefit is related to mutually agreed advance financing, temporarily uncertain economic effect of use, but potentially capable of its unlimited oculation, expected high potential of value added; (c) the benefit is accompanied by a social effect in the event of use; (d) the benefit is characterized by relatively low costs of restricting access to it for consumers; (e) effective provision and dissemination of benefits occurs with the mixed participation of innovative institutional agents of the national economy; (f) the benefit of using FR\&D in the event of publication is indivisively divided across society regardless of whether or not individual representatives want to acquire it.

The need for the implementation of FR\&D is an emotional state capable of creative social group of research scientists and society as a whole, which expresses dependence on the objective content of conditions of existence and development and acts as a source of various forms of activity in the public interest. The potential of FR\&D implementation is the ability to intensify the processes of purposeful, costly, long-term nonlinear, multi-stage and cumulative learning, which leads to interactive, technologically specialized and culturally determined constant innovation activities of universities with the subsequent receipt of market advantages.

\section{Acknowledgement}

The paper was supported by Erasmus+ Project № 609944-EPP-1-2019-1-LT-EPPKA2-CBHE-JP “Enhancing Capacity of Universities to Initiate and to Participate in Clusters Development on Innovation and Sustainability Principles".

\section{Conflict of interests}

The authors declare no conflict of interest 


\section{References}

Achinstein P. and Barker, S.F. (1969). The Legacy of Logical Positivism: Studies in the Philosophy of Science. Johns Hopkins Press, 1969. 300 p.

Agassi, J. (1968). The Novelty of Popper's Philosophy of Science. Intern. Phil. Quart., 1968. Vol. 8. Philosophy Documentation Center. Retrieved from: https:// www.pdcnet.org/ipq/content/ipq_1968_0008_0003_0442_046 (accessed: December 2020).

Albert H. Historiography as a Hypothetical-Deductive Science: A Criticism of Methodological Historism. Rationality and Reality. Conversations with Alan Musgrave / Cheyne C., Worrall J. (eds). Dordrecht: Springer. Retrieved from: https://doi.org/10.1007/1-4020-4207-8_15 (accessed: 30.10.2019)

Albert, H. (1987). Science and the Search for Truth. Rationality: The Critical View / Agassi J., Jarvie I.C. (eds). Dordrecht: Springer. Nijhoff International Philosophy Series, 1987. Vol 23. Retrieved from: https://doi.org/10.1007/978-94-009-3491-7_6 (accessed: December 2020).

Ayer, A. (1959). Logical positivism. The Free Press, New York. Retrieved from: https://issuu.com/epistemologiasabado/docs/ayer--a.-j.---logical-positivism (accessed: December 2020)

Barnes, B. (1974). Scientific Knowledge and Sociological Theory. Routledge and Keagan Paul, London. 204 p.

Barnes, B. and Shapin, S. (1979). Natural Order: Historical Studies of Scientific Culture. Sage Publication, London. 251 p.

Bartley, W. (1964). "Rationality versus the Theory". Bunge M. (ed.). The Critical Approach to Science and Philosophy. Free Press, New York. Retrieved from: https://www.taylorfrancis.com/books/e/9781351313087/ chapters/10.4324/9781351313087-1 (accessed: December 2020).

Bantash, A., Koval, V., Bashynska, M., \& Kozlovtseva, V. (2020). Balanced territorial economic development in the conditions of providing stability of human resources management. Economics. Ecology. Socium, 4(3), 58-66. https://doi.org/10.31520/2616-7107/2020.4.3-6

Bell, D. (1973). The Coming of Post-Industrial Society: A Venture in Social Forecasting. N.Y.: Basic Books, 1973.618 p.

Bogomolov, A. (1962). Filosofiya anglo-amerikanskogo neorealizma / Philosophy of Anglo-American Neorealism. Moscow State University, Moscow. 88 p. (RU)

Bogomolov, A. (1969). Nemetskaya burzhuaznaya filosofiya posle 1865 g. / German bourgeois philosophy after 1865. Moscow State University, Moscow. 448 p. (RU)

Carnap, R. (1971). Filosofskiye osnovaniya fiziki. Vvedeniye v filosofiyu nauki / Philosophical Foundations of Physics. Introduction to the philosophy of science. Progress, Moskow. 390 p.

Charlesworth, M.J. (1959). Philosophy and Linguistic Analysis. Published by Duquesne University. 234 p.

Dewey, J. (2001). Rekonstruktsiya v filosofii / Reconstruction in Philosophy / trans. from English. Zanadvorov M., Shikov M. Logos, Moscow. 94 p.

Elkana, Y. (1981). “A Programmatic Attempt at an Anthropology of Knowledge”. Mendelsohn Everett, Elkana Yehuda (eds.). Sciences and cultures: anthropological and historical studies of the sciences. Springer Netherland, Vol. 5. pp. $1-68$.

Engels, F. (2013). Herrn Eugen Dührings Umwälzung der Wissenschaft (German Edition). Holzinger: Taschenbuck. 312 p.

Engels, F. (2017). Dialektik der Natur (German Edition). OK Publishing. 282 p.

Feyerabend P. Stanford Encyclopedia of Philosophy. URL: https://plato. stanford.edu/entries/feyerabend/ (accessed: 31.10.2019).

Feyerabend, P. (1975). Against Method. London: Verso, 279 p. Retrieved from: https://monoskop.org/images/7/7e/Feyerabend_Paul_Against_Method.pdf (accessed: December 2020)

Feyerabend, P. (1978). Science in a Free Society. London: New Left Books. 221 p.

Frank, F. (2007). Filosofiya nauki: Svyaz' mezhdu naukoy i filosofiyey / Philosophy of Science: Communication between Science and Philosophy / transl. from English; total ed. G.A. Kursanov; ed. 2nd.: LKI Publishing House, Moscow. Retrieved from: http://www.vixri.com/d/Frank\%20F.\%20\%20_FILOSOFIJa\%20NAUKI.pdf (accessed: December 2020). 
Galbraith, J.K. (1985). The New Industrial States. Princeton and Oxford: Princeton University Press, 1985. 567 p.

Gryaznova, A. (1993). Analiticheskaya filosofiya / Analytical philosophy. Available at: https:// platona.net/load/knigi_po_filosofii/analiticheskaja_filosofija/analiticheskaja_filosofija_izbrannye_teksty_sost_i_k omment_a_f_grjaznova_1993/28-1-0-1017 (accessed: December 2020).

Husserl, E. (1994). Filosofiya kak strogaya nauka / Philosophy as a strict science.: Saguna, Novocherkassk. 357 p. (RU)

James, W. and Russell, B. (2000). Vvedeniye v filosofiyu. Problemy filosofii / Introduction to Philosophy. Philosophy problems. Republic, Moscow. 318 p. (RU)

Kuhn, T. (2001). Struktura naukovykh revolyutsiy / The structure of scientific revolutions. Kyiv: Port-Royal, 2001. Collection. Retrieved from: http://izbornyk.org.ua/kuhn/kuhn.htm (accessed: December 2020).

Lakatos, I. (2008). Izbrannyye proizvedeniya po filosofii $i$ metodologii nauki / Selected Works on Philosophy and Methodology of Science / per. from English Veselovsky I.N., Nikiforova A.L., Porusa V.N. Academic Project; Tricksta, Moscow. 475 p.

Lange, F.A. (1866). Geschichte des Materialismus und Kritik seiner Bedeutung in der Gegenwart: Buch 1: Geschichte des Materialismus bis auf Kant. Leipzig: Iserlohn, Leipzig. $452 \mathrm{s.}$

Liebmann, O. (1865). Kant und die Epigonen. Eine kritische Abhandlung. Harald Fisher Verlag, Stuttgart. 220 s.

Marx, K. (1969). Thesen über Feuerbach. Marx-Engels Werke, Band 3, Seite 5ff. Dietz Verlag Berlin.

Merton R.K. The Sociology of Science. Chicago and London: The University of Chicago Press, 1973. 605 p.

Narsky, I. (1961). Sovremennyy pozitivizm / Modern positivism. AN SSSR, Moscow, 423 p.

OECD. 2005. Oslo Manual. The measurement of scientific and technological activities. Proposed Guidelines for Collecting and Interpreting Innovation Data, 3nd Edition. 2005. Retrieved from: https://www.oecd-ilibrary.org/ docserver/9789264013100-en.pdf?expires $=1603171707 \&$ id=id\&accname=guest\&checksum $=$ A9451010DECB2EA8CC91EFF9D2BF2EFA (accessed: December 2020)

Panin, A. (1981). Dialekticheskiy materializm i postpozitivizm (kriticheskiy analiz nekotorykh sovremennykh burzhuaznykh kontseptsiy nauki) / Dialectical materialism and post-positivism (a critical analysis of some modern bourgeois concepts of science). Moscow State University Publishing House, Moscow, 240 p.

Popper, K. (1956). Three views concerning human knowledge. Contemporary British philosophy. Allen \& Unwin, L.N.Y. 366 p.

Popper, K. (1983). Logika i rost nauchnogo znaniya / Logic and the growth of scientific knowledge. Moscow: Progress, 1983. $605 \mathrm{p}$.

Popper, K. (2002). Conjectures and Refutations: The Growth of Scientific Knowledge. $2^{\text {nd }}$ ed. Routledge, London. 608 p.

Popper, K. (2005). Logika nauchnogo issledovaniya / Logic of scientific research / trans. from English; under total. ed. Sadovsky V.N. Republic, Moscow. 447 p.

Petrova, M., Koval, V., Tepavicharova, M., Zerkal, A., Radchenko, A., \& Bondarchuk, N. (2020). The interaction between the human resources motivation and the commitment to the organization. Journal of Security and Sustainability Issues, 9(3), 897-907. https://doi.org/10.9770/jssi.2020.9.3(15)

Spinner, H.F. (1978). Popper und die Politik: Rekonstruktion und Kritik der Sozial-, Polit- und Geschichtsphilosophie des Kritischen Rationalismus. Bonn: Dietz Nacht, Bonn. 624 p.

Tarsky, A. (1948). Vvedeniye v logiku i metodologiyu deduktivnykh nauk / Introduction to the logic and methodology of deductive sciences. GIIL, Moscow. 327 p.

Wittgenstein, L. (1969). On Certainly (Uber Gewissheit) / trans. Paul D. \& Anscombe G.E.M. Oxford: Basil Blackwell, Oxford. 90 p. 


\section{About the author:}

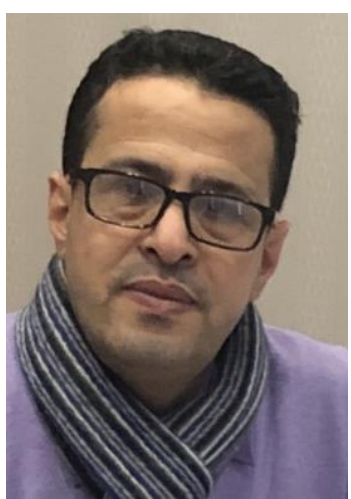

\section{Al-Ghazali Ameen SAIF ALI,}

Ministry of Defense, diplomatic representative Republic of Yemen; PhD student in Central Ukrainian National Technical University, Kropivnitskyi, Ukraine.

Research interests: fundamental scientific research, cognitive society, business administration, consumer behavior.

ORCID ID: https://orcid.org/0000-0002-4524-7360

Copyright (C) 2020 by author(s) and ACCESS Publishing Press This work is licensed under the Creative Commons Attribution International License (CC BY) 